\section{Misclassification of pest as 'fungus' puts vital research on wrong track}

Sir - In your News report on the reemergence of late blight in Russia ${ }^{1}$, the causal agent is referred to as "the fungus Phytopthora infestans". The genus name literally means 'plant destroyer' and is derived from the Greek words phyton and phthora, so the correct spelling is Phytophthora infestans.

Phytophthora is grouped in the class of Oomycetes, which behave like fungi in that their main body consists of a network of hyphae that grow at the tip, and they propagate via spores. Yet they are no longer classified in the kingdom Fungi.

Molecular phylogenetic analysis has clearly demonstrated that Oomycetes evolved completely independently from the true fungi - the Ascomycetes and Basidiomycetes - and instead are more closely related to golden-brown algae and heterokont algae in the eukaryotic crown group of Stramenophiles. Lynn Margulis ${ }^{2}$ has classified them in the kingdom Protoctista.

Hence, it is debatable whether access to fungicides would help small farmers in Russia to fend off a potato famine. The misconception that $P$. infestans is a fungus has put us on the wrong track for decades. Many fungicide targets are absent in oomycetes, and our knowledge of their biology is limited. New approaches are needed to find novel drug targets and to develop what I suggest should be called 'oomicides'.

Understanding the biology of oomycetes should reveal how these notorious pathogens interact with plants and why host resistance is lost so quickly, providing new leads for durable resistancebreeding strategies.

The aggressive strains currently prevailing in Russia, Western Europe and the United States are the result of a worldwide population displacement of P. infestans that started in the mid-1970s. Unlike the earlier infestation discussed in your News report that caused the Irish famine in the 1840s (see this issue, pages 644 and 695), the 1970s infestation included strains with the two different mating types ${ }^{3,4}$, so $P$. infestans can now propagate sexually in almost every area in the world where potatoes are grown. The egg-shaped sexual spores, oospores, can survive in soil independent of the host plant and can act as an extra inoculum source early in the growing season. Moreover, sexual recombination allows the pathogen to adapt even more easily to adverse conditions.
Fending off a potato famine in Russia requires more than access to suitable pesticides for small farmers. What is really needed is a rational design of control strategies, based on knowledge of the behaviour of the late-blight pathogen and on implementation of this knowledge by pathologists, breeders, biotechnologists and agronomists.

Francine Govers

Laboratory of Phytopathology, Wageningen

University, Binnenhaven 9, 6709, PD Wageningen,

The Netherlands

1. Nature 410, 1011 (2001).

2. Margulis, L. \& Schwartz, K.V. Five Kingdoms: An Illustrated Guide to the Phyla of Life on Earth (3rd edn) 109-202 (W. H. Freeman, New York, 1998).

3. Drenth, A., Tas, I. C. Q. \& Govers, F. Eur. J. Plant Pathol. 100, 97-107 (1994).

4. Fry, W. E. et al. Ann. Rev. Phytopathol. 30, 107-130 (1992).

\section{Drug test warning}

Sir - Your News article "Researchers strike back in animal-rights row" (Nature 411, 7; 2001) prompts me to ask why drug manufacturers do not put prominent labels on their products comparable to the health warnings on cigarette packets, stating "Development of this drug was made possible by ethically controlled tests on animals"? This would give animalrights activists and the public a regular opportunity to see the implications of the alternatives available when they come to need, for example, a modern painkiller or chemotherapeutic cancer drug.

\section{T. C. Whitmore}

Department of Geography, University of Cambridge, Downing Place, Cambridge CB2 3EN, UK

\title{
e-access
} Nature's debate on access continues at i http://www.nature.com/nature/debates/e-access/index.html.

\section{Who is prepared to pay, and how much?}

Sir - Free or fee, is that the question facing science journal publishers? It shouldn't be. Whatever the method of publishing, it is not without costs. The question should be: who pays the fees and are they reasonable?

As a publishing and information consultant, I find there are two elements that make science journal publishing a somewhat unusual industry. First, journals and the articles published in them are monopolies; no article is published more than once and, once published, an article is available only from the original publisher, although sometimes indirectly (for example via document delivery services). Second, users - authors and readers - do not usually pay for subscriptions or licences; those who do are usually not users. The science journal publishing industry has been likened to the cat food industry: the consumer may be very discerning, but the owner buys the food.

This lack of a 'free market' and its competitive mechanisms means that journal publishing does not follow the usual economic laws of supply and demand. Prices are detached from value or quality, real or perceived, and pricing practices are based on costs plus profit expectations, which are largely at the discretion of the publishers. There is no market correction of prices as a result of competition. Assuming that costs are similar for most publishers, variations in profit expectations cause much of the problem of high prices faced by libraries.

The costs of publishing are growing. For example, the growth in the number of papers published means that even without profit margins, libraries cannot maintain anything like a comprehensive collection in their chosen fields, unless unit costs are massively reduced. Those who support the Public Library of Science initiative clearly believe that the costs can be so low that recouping them in only six months would be feasible. They may be right, but profit margins of the kind the industry is used to will be reduced, and publishers will not give up these profits willingly. What is needed is the introduction of true commercial competition with the development of viable new business models. In these, the costs should be kept to a bare minimum, the balance of payments (who pays what proportion of the costs) should be addressed and profit margins should be within a range that most parties would consider fair.

Costs can be kept low by taking full advantage of electronic technology. The balance of payments can be addressed by asking those who arguably benefit most - authors - to pay their share in submission charges. Large profit margins are likely to be reduced in such models in any event.

Peer-reviewed research papers could be accessible via the Internet at very low prices or even free of charge to the reader, and print editions could be made available on demand. BioMed Central (http://www. biomedcentral.com) seems to be developing in that direction. It has a good chance of being successful if authors can be persuaded that paying submission charges is in their interest, and if costs can be kept low enough to be covered by those charges. Supplementary revenue from advertising and sponsorship, if sustainable, can lower the thresholds of viability.

More of these models and the science publishing industry might see some real competition!

Johannes Velterop

9 Benfleet Close, Cobham, Surrey KT11 2NR, UK 